\title{
Penggunaan LKPD Untuk Meningkatkan Hasil Belajar Peserta Didik Pada Materi
}

\author{
Matriks \\ As'ar Musrimin Hadi \\ SMK Negeri 1 Tirawuta Sulawesi Tenggara, Indonesia \\ Email: asmusrimin@gmail.com
}

\begin{abstract}
Abstrak
Penelitian Tindakan Kelas ini bertujuan meningkatkan hasil belajar siswa pada materi matriks kelas XI OTKP SMK Negeri 1 Tirawuta setelah diterapkannya penggunaan LKPD dalam proses pembelajaran. Subjek penelitian ini adalah siswa kelas XI OTKP SMK Negeri 1 Tirawuta tahun pelajaran 2020/2021 yang berjumlah 18 siswa. Penelitian ini dilaksanakan dalam 2 siklus, pada tiap siklusnya terdiri dari empat tahapan yaitu perencanaan, tindakan, observasi, dan refleksi. Teknik pengumpulan data yang digunakan yakni teknik kualitatif. Teknik analisis data kualitatif digunakan untuk mendeskripsikan pelaksanaan pembelajaran di kelas berupa Observasi dan hasil catatan lapangan. Siklus akan berhenti jika indikator keberhasilan telah tercapai. Hasil penelitian menunjukkan bahwa penggunaan lembar kerja peserta didik dapat meningkatkan aktivitas dan hasil belajar siswa pada materi matriks. Hal ini dibuktikan dengan adanya peningkatan hasil belajar siswa dari siklus I ke siklus II. Peningkatan hasil belajar siswa ditunjukan dari tes akhir siklus. Pada siklus I diperoleh nilai rata-rata sebesar 68 dan ketuntasan klasikal sebesar $61,11 \%$. Sedangkan pada siklus 2 nilai rata-rata kelas naik menjadi 82,92 dan ketuntasan belajar klasikal sebesar $88,89 \%$. Hasil penelitian ini dapat disimpulkan bahwa penggunaan lembar kerja peserta didik berhasil meningkatkan hasil belajar siswa pada materimatriks.
\end{abstract}

Kata Kunci : Hasil belajar, lembar kerja peserta didik

\begin{abstract}
This classroom action research aims to improve student learning outcomes in the matrix material for class XI OTKP at SMK Negeri 1 Tirawuta after the use of $L K P D$ in the learning process. The subjects of this study were 18 students of class XI OTKP of SMK Negeri 1 Tirawuta in the academic year 2020/2021. This research was conducted in 2 cycles, each cycle consisting of four stages, namely planning, action, observation, and reflection. The data collection technique used is qualitative techniques. Qualitative data analysis techniques are used to describe the implementation of learning in the classroom in the form of observations and field notes results. The cycle will stop when the indicators of success have been reached. The results showed that the use of student worksheets could increase student activity and learning outcomes in the matrix material. This is evidenced by the increase in student learning outcomes from cycle I to cycle II. The increase in student learning outcomes is shown from the final cycle test. In the first cycle obtained an average value of 68 and classical completeness of $61.11 \%$. While in cycle 2 the class average value increased to 82.92 and classical learning completeness by $88.89 \%$. The results of this study concluded that the use of student worksheets was successful in improving student learning outcomes in the matrix material.

Keywords: Learning outcomes, student worksheets
\end{abstract}


PENDAHULUAN

Pendidikan merupakan usaha untuk mengembangkan dan membina sumber daya manusia melalui berbagai kegiatan belajar mengajar yang diselenggarakan pada semua jenjang pendidikan di tingkat dasar, menengah dan perguruan tinggi.

Pendidikan di sekolah mempunyai tujuan untuk mengubah siswa agar dapat memiliki pengetahuan, keterampilan, nilai dan sikap belajar sebagai bentuk dari hasil belajar atau interaksi antara guru dan siswa. Pendidikan di sekolah tidak dapat dilepaskan dari proses pembelajaran. Proses pembelajaran memiliki peranan penting dalam dunia pendidikan yaitu untuk menambah ilmu pengetahuan dan keterampilan. Pembelajaran merupakan suatu kegiatan yang dilakukan oleh guru dengan sedemikian rupa sehingga tingkah laku siswa dapat berubah kearah yang lebih baik.

Hasil belajar menggambarkan
kemampuan peserta didik dalam
mempelajari sesuatu. Hal ini sesuai
dengan pendapat Nana Sudjana (Anisa
Firdaus: 2013) yang menyebutkan bahwa:
"Hasil belajar adalah kemampuan yang
dimiliki atau dikuasai peserta didik
setelah menempuh proses belajar".

Hasil belajar mencakup kemampuan kognitif (intelektual), afektif (sikap), dan kemampuan psikomotorik (bertindak). Harus diakui bahwa dalam proses belajar mengajar, terutama yang berkenaan dengan perubahan konsep matriks, sedikit sekali kemempuan yang berkenaan dengan sikap, yang lebih banyak adalah aspek kognitif dan psikomotorik. Dalam aspek kognitif ada enam unsur yang saling berkaitan satu dengan yang lainnya, yaitu pengetahuan, pemahaman, aplikasi, analisis, sintesis, dan evaluasi.

Pengalaman selama proses pembelajaran matematika yang dilakukan di SMK Negeri 1 Tirawuta adalah pembelajaran yang berpusat pada guru dengan metode ceramah. Dengan metode ceramah yang dilakukan oleh guru, peserta didik masih belum terlibat aktif dalam kegiatan pembelajaran. Peserta didik hanya terlibat dalam tanya jawab yang sesekali dilakukan oleh guru ketika menyampaikan materi. Selama berlangsungnya pembelajaran, guru juga tidak pernah menggunakan metode diskusi kelompok dalam pembelajaran, sehingga interaksi dan komunikasi hanya terjalin antara guru dengan peserta didik secara umum. 
Dari hasil belajar Penilaian Tengah Semester Ganjil tahun pelajarran 2020/2021 kelas XI OTKP diperoleh nilai rata-rata 59 dimana masih berada dibawah nilai Kriteria Ketuntasan Minimal (KKM) yang ditetapkan sekolah yakni 70 .

Lembar kerja peserta didik (LKPD) menurut Depdiknas (2008) merupakan salah satu sarana yang dalam proses pembelajaran dapat membantu dan mempermudah kegiatan pembelajaran sehingga pembelajaran yang terjadi mampu mengiringi peseta didik untuk menemukan konsep yang bisa digunakannya dalam menyelesaikan masalah secara sistematis.

LKPD dapat pula dijadikan sumber belajar untuk meningkatkan aktivitas dan hasil belajar siswa. Dengan adanya aktivitas dalam belajar maka, siswa dapat terkembangkan potensi belajarnya. Apabila potensi belajar meningkat, maka hasil belajar meningkat dan tujuan pembelajaran dapat tercapai dengan optimal karena dalam lembar kerja tersebut ada tuntutan yang harus dikerjakan oleh siswa seperti latihan-latihan soal dan ada sedikit materi untuk membahas dan memecahkan masalah yang harus dikerjakan oleh siswa. Dengan seringnya siswa berlatih mengerjakan soal-soal latihan maka wawasan dan kemampuankemampuan analisis memecahkan masalah serta daya kreativitas mereka akan bertambah dan apabila siswa dilibatkan penuh pada kegiatan pembelajaran seperti memecahkan suatu persoalan maka aktivitas dalam proses pembelajaranpun akan terlihat, sehingga LKPD dapat meningkatkan aktivitas dan menambah wawasan bagi siswa untuk meningkatkan hasil belajar, khususnya pada materi Matriks. Pemahaman konsep yang baik (Suryanti, Khikmiyah, Zawawi, \& Fauziyah, 2014), pada melalui LKPD yang nantinya akan mengarahkan pada peningkatan hasil belajar.

Berdasarkan latar belakang diatas penulis berinisiatif untuk melakukan penelitian tindakan kelas yang berjudul "Penggunaan LKPD untuk meningkatkan hasil belajar peserta didik pada materi Matriks di kelas XI OTKP SMK Negeri 1 Tirawuta Tahun Pelajaran 2020-2021" diharapkan minimal $75 \%$ peserta didik di kelas tersebut memperoleh ketuntasan hasil belajar.

Berdasarkan latar belakang masalah di atas maka dapat diidentifikasi masalah-masalah sebagai berikut:

1. Proses pembelajaran matematika yang masih monoton.

2. Suasana kelas tindak kondusif selama proses pembelajaran matematik berlangsung. 
3. Siswa menganggap pembelajaran matematika menjenuhkan dan membosankan.

4. Sumber belajar dan bahan ajar yang digunakan masih kurang.

5. LKPD dalam proses pembelajaran masih kurang.

6. Aktivitas dan keterlibatan siswa dalam proses pembelajaran matematika masih kurang.

7. Hasil belajar siswa rendah pada mata pelajaran matematika.

Berdasarkan identifikasi masalah dan analisis masalah di atas, maka rumusan masalah yang dapat ditulis adalah "Apakah penggunaan LKPD dapat meningkatkan hasil belajar peserta didik pada materi matriks kelas XI OTKP SMK Negeri 1 Tirawuta tahun pelajaran 2020 2021?"

Adapun tujuan penelitian tindakan kelas ini dilakukan adalah untuk meningkatkan hasil belajar siswa pada materi matriks kelas XI OTKP SMK Negeri 1 Tirawuta tahun pelajaran 2020 2021 setelah diterapkannya penggunaan LKPD dalam proses pembelajaran.

Menurut Arikunto, dkk (2006), penelitian tindakan kelas merupakan suatu pencermatan terhadap kegiatan belajar berupa tindakan, yang sengaja dimunculkan dan terjadi dalam sebuah kelas secara bersama. Penelitian yang dilakukan bertujuan untuk memperbaiki situasi pembelajaran di kelas, agar terjadi peningkatan kualitas pembelajaran.

Wijaya Kusumah dan Dedi Dwitagama (2011:9) menyatakan penelitian tindakan kelas adalah penelitian (action research) yang dilakukan oleh guru di dalam kelas dan memiliki rangkaian "riset - tindakan riset - tindakan - riset - tindakan - ...", yang dilakukan dalam rangkaian untuk memecahkan masalah.

Menurut Ani Widayati (2008), penelitian tindakan kelas adalah suatu kegiatan penelitian yang berkonteks kelas yang dilaksanakan untuk memecahkan masalah-masalah pembelajaran yang dihadapi oleh guru, memperbaiki mutu dan hasil pembelajaran dan mencoba halhal baru dalam pembelajaran demi peningkatan mutu dan hasil pembelajaran.

Penelitian tindakan kelas merupakan kegiatan penelitian yang dapat dilakukan secara individu maupun kolaboratif. Penelitian tindakan kelas individual merupakan penelitian di mana seorang guru melakukan penelitian di kelasnya maupun kelas guru lain. Sedangkan penelitian tindakan kelas kolaboratif merupakan penelitian di mana beberapa guru melakukan penelitian secara sinergis di kelasnya dan anggota 
yang lain berkunjung ke kelas untuk mengamati kegiatan.

Penelitian tindakan kelas harus menunjukkan adanya perubahan ke arah perbaikan dan peningkatan secara positif. Apabila dengan tindakan justru membawa kelemahan, penurunan atau perubahan negatif, berarti hal tersebut menyalahi karakter penelitian tindakan kelas. Karakteristik yang menunjukkan ciri dari penelitian tindakan kelas adalah sebagai berikut: 1) Inkuiri reflektif. Penelitian tindakan kelas berangkat dari permasalahan pembelajaran riil yang sehari-hari dihadapi oleh guru dan peserta didik. Jadi, kegiatan penelitian berdasarkan pada pelaksanaan tugas (practice driven) dan pengambilan tindakan untuk memecahkan masalah yang dihadapi (action driven). 2). Kolaboratif. Upaya perbaikan proses dan hasil pembelajaran tidak dapat dilakukan sendiri oleh peneliti di luar kelas, tetapi ia harus berkolaborasi dengan peserta didik. Penelitian tindakan kelas merupakan upaya bersama dari berbagai pihak untuk mewujudkan perbaikan yang diinginkan.

Reflektif. Penelitian tindakan kelas memiliki ciri khusus, yaitu sikap reflektif yang berkelanjutan. Berbeda dengan pendekatan penelitian formal, yang sering mengutamakan pendekatan empiris eksperimental, penelitian tindakan kelas lebih menenkankan pada proses reflektif terhadap proses dan hasil penelitian.

Hasil belajar tampak sebagi terjadinya perubahan tingkah laku pada diri peserta didik, yang dapat diamati dan diukur dalam bentuk perubahan pengertahuan sikap dan keterampilan. Perubahan tersebut dapat diartikan terjadinya perubahan dan perkembangan yang lebih baik dibandingkan dengan sebelumnya, seperti dari tidak bisa menjadi bisa, dari tidak sopan menjadi sopan, dan sebagainya.

Hasil belajar menggambarkan kemampuan peserta didik dalam mempelajari sesuatu. Hal ini sesuai dengan pendapat Nana Sudjana (Anisa Firdaus: 2013) yang menyebutkan bahwa: "Hasil belajar adalah kemampuan yang dimiliki atau dikuasai peserta didik setelah menempuh proses belajar". Hasil belajar mencakup kemampuan kognitif (intelektual), afektif (sikap), dan kemampuan psikomotorik (bertindak). Harus diakui bahwa dalam proses belajar mengajar, terutama yang berkenaan dengan perubahan konsep sistem persamaan linier dua variabel, sedikit sekali kemempuan yang berkenaan dengan sikap, yang lebih banyak adalah aspek kognitif dan psikomotorik. Dalam aspek kognitif ada enam unsur yang saling 
berkaitan satu dengan yang lainnya, yaitu pengetahuan, pemahaman, aplikasi, analisis, sintesis, dan evaluasi.

Menurut Nana Sudjana, (Anisa Firdaus: 2013) Tujuan pendidikan yang ingin dicapai dapat dikategorikan menjadi tiga bidang, yaitu bidang kognitif (penguasaan intelektual), bidang afektif (berhubungan dengan sikap dan nilai) dan bidang psikomotorik (kemampuan/keterampilan

bertindak/berperilaku). Ketiganya tidak berdiri sendiri, tapi merupakan satu kesatuan yang tak terpisahkan, bahkan membentuk hubungan hirarki. Sebagai tujuan yang hendak dicapi, ketiganya harus Nampak sebagai hasil belajar peserta didik disekolah. Oleh sebab itu, ketiga aspek tersebut harus dipandang sebagai hasil belajar peserta didik dari proses pengajaran.

Berdasarkan uraian diatas, hasil belajar matematika berarti penguasaan terhadap materi pelajaran matematika, meningkatnya sikap positif terhadap matematika, serta terampil menggunakan matematika untuk memecahkan persoalan-persoalan dalam kehidupan sehari-hari.

\section{METODE}

Penelitian ini merupakan penelitian tindakan kelas yang dilakukan di Sekolah Menengah Kejuruan Negeri 1
Tirawuta. Penelitian dilakukan selama bulan Oktober-Nopember 2020 dengan 18 siswa kelas XI TKRO sebagai subjek penelitian. Jadwal kegiatan penelitian ini tercan-tum dalam Tabel 1, yang menunjukkan bahwa kegiatan penelitian tindakan kelas dilakukan selama dua siklus yang terdiri dari kegiatan perencanaan, pelaksanaan dan refleksi. Materi pembelajaran yang dipilih adalah "Jenis-Jenis Matriks dan Kesamaan dua Matriks" pada siklus I dan "Operasi Penjumlahan dan Pengurangan Matriks" pada siklus berikutnya

Tabel 1. Jadwal Kegiatan Penelitian di SMKN 1 Tirawuta

\begin{tabular}{clc}
\hline No. & \multicolumn{1}{c}{ Kegiatan } & Tanggal \\
\hline 1. & Perencanaan I & $19 / 10 / 2020$ \\
2. & Pelaksanaan I & $22 / 10 / 2020$ \\
3. & Refleksi I & $24 / 10 / 2020$ \\
4. & Perencanaan II & $31 / 10 / 2020$ \\
5. & Pelaksanaan II & $2 / 11 / 2020$ \\
6. & Refleksi II & $4 / 11 / 2020$ \\
\hline
\end{tabular}

Hasil tes peserta didik dianalisis untuk menentukan peningkatan ketuntasan peserta didik, nilai individu, dan nilai rata-rata klasikal.

1) Peningkatan ketuntasan mengikuti ketentuan sekolah, yaitu peserta didik dinyatakan tuntas jika memperoleh nilai $\geq 70$. Untuk menentukan persentase ketuntasan peserta didik menggunakan perhitungan persen (\%) ketuntasan, yaitu sebagai berikut: 
Persen (\%) ketuntasan

$$
\begin{aligned}
& =\frac{\text { jumlah siswa tuntas }}{\text { jumlah siswa }} \\
& \times 100 \%
\end{aligned}
$$

2) Peningkatan hasil belajar peserta didik juga dilihat dari peningkatan nilai rata-rata tes yang diberikan di setiap siklus. Nilai rata-rata peserta didik diperoleh dengan menggunakan perhitungan sebagai berikut: $\bar{x}=$ $\frac{\sum_{i=1}^{n} x_{i}}{n}$

Dengan:

$\bar{x}=$ rata-rata

$x_{i}=$ nilai siswa

$n=$ jumlah siswa

\section{HASIL DAN PEMBAHASAN}

Hasil penelitian dijelaskan secara deskriptif mulai dari observasi, pelaksanaan siklus I dan pelaksanaan siklus II.

\section{Siklus 1}

Catatan lapangan (kejadian-kejadian penting)

Setelah melakukan pengamatan saat pembelajaran yang telah dilakukan, maka diperoleh hasil observasi kegiatan peserta didik sebagai berikut:

Pertama, beberapa siswa malu bertanya dan enggan mengemukakan jawaban
Gambar 1. siswa masih bekerja sendiri

Kedua, masih bingung menggunakan LKPD dan hanya mengikuti jawaban temnannya yang aktif.

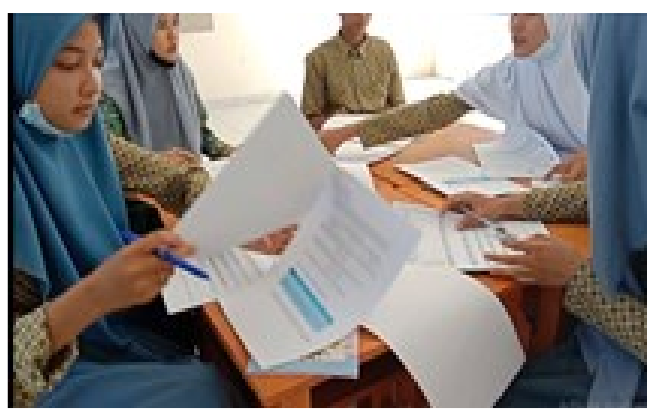

Gambar 2. siswa masih bingung dengan menggunakan LKPD

Ketiga Masih malu untuk mempresentasikan jawaban ke depan kelas, masih ragu-ragu dalam menyampaikan jawaban, masih banyak siswa yang tidak menyimak temannya yang sedang menyampaikan jawaban
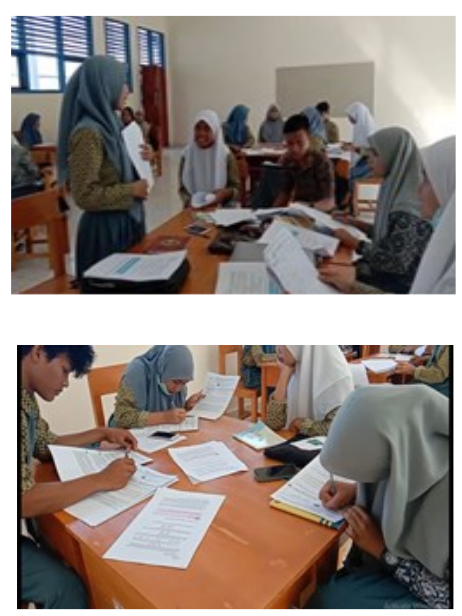

Gambar 3. Siswa masih malu meyampaikan jawaban diskusi 
Hasil belajar peserta didik

Pada akhir pembelajaran, guru memberikan evaluasi kepada pesertra didik. Hasil yang diperoleh adalah sebagai berikut:

Tabel 3. Hasil Tes Evaluasi Siklus 1

\begin{tabular}{|c|l|c|}
\hline No & Hasil Tes Evaluasi I & Siklus I \\
\hline 1 & Rata-rata & 68 \\
\hline 2 & Tuntas & $61,11 \%$ \\
\hline 3 & Tidak Tuntas & $38,89 \%$ \\
\hline 4 & Ketuntasan belajar & Belum \\
& Secara klasikal & Tuntas \\
\hline 5 & Jumlah Siswa & 18 siswa \\
\hline
\end{tabular}

Berdasarkan tabel di atas, pada siklus 1 diperoleh ketuntasan belajar yaitu 61,11\%. Dari nilai persentase tersebut belum mencapai ketuntasan $75 \%$ yang diharapkan karena masih terdapat 38,89 $\%$ siswa yang mendapatkan nilai dibawah $\mathrm{KKM}=70$.

Berikut grafik persentase ketuntasan hasil belajar siswa pada siklus 1

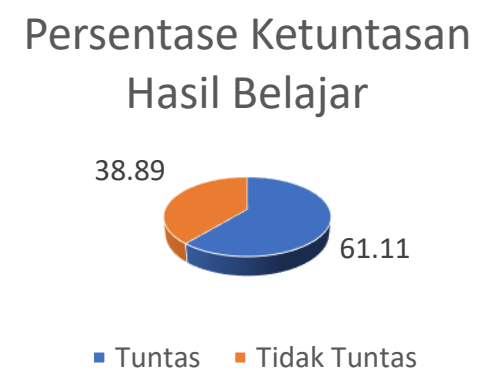

Grafik 1 tuntasan belajar siklus 1

Dari grafik diatas tampak bahwa ketunatsan secara klasikal 61,11 \% dan tidak tuntas sebesar 38,89\% dimana nilai ketuntasan belum mencapai nilai persentase yang diharapkan sebesar $75 \%$

Berdasarkan data ketuntasan hasil belajar siswa yang belum mencapai $\geq 75$ $\%$. Oleh sebab itu hasil belajar perlu ditingkatkan melalui perbaikan tindakan yang dilaksanakan untuk diterapkan pada siklus II.

\section{Siklus 2}

Tahap perencanaan sikus II adalah kegiatan peneliti dalam mempersiapakan RPP, bahan ajar, media pembelajaran, LKPD, rubrik penilaian dan soal evaluasi. Peneliti dalam menyusun RPP melakukan diskusi dengan Dosen. RPP yang dibuat sesuai dengan materi yang sedang berjalan. Catatan lapangan diisi oleh peneliti untuk mencatat kejadian-kejadian selama tindakan berlangsung dan kondisi belajar siswa saat menggunakan LKPD dalam pebelajaran

Pada tahap pelaksanaan ini peneliti melaksanakan RPP yang telah disusun dalam perencanaan. Sesuai dengan perencanaan siklus II terjadi 1 kali pertemuan. Pertemuan berlangsung pada tanggal 2 Nopember 2020. Pembelajaran di siklus II dibagi menjadi 3 kegiatan, yaitu pendahuluan, kegiatan inti, dan penutup. 


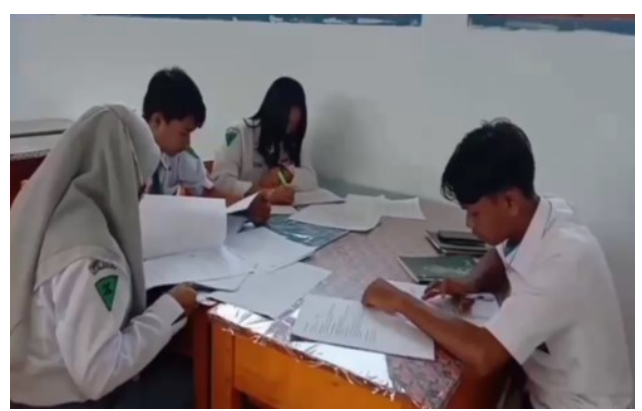

Gambar 4. Siswa berdiskusi mengerjakan LKPD

Pada pelaksanaan pembelajaran di siklus 2 siswa antusias memperhatikan penjelasan guru, tidak malu lagi untuk menjawab, Terlihat semangat dalam menyampaikan jawaban.

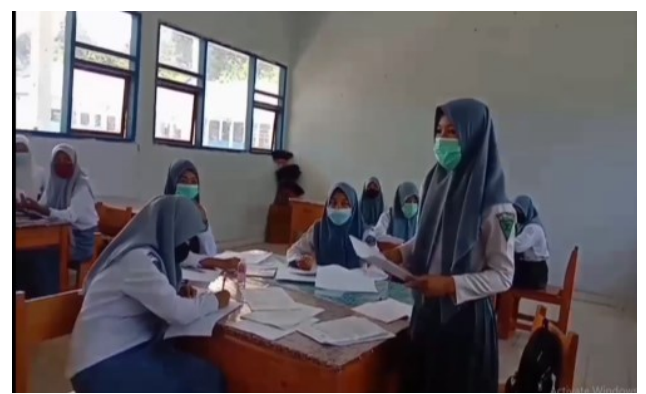

Gambar 5. Siswa menyampaikan Jawaban

Semangat dalam mengerjakan LKPD, Siswa senang karena dapat bertukar pikiran, tidak malu lagi bertanya dan berdiskusi dan lebih bersemangat dalam menyampaikan jawaban

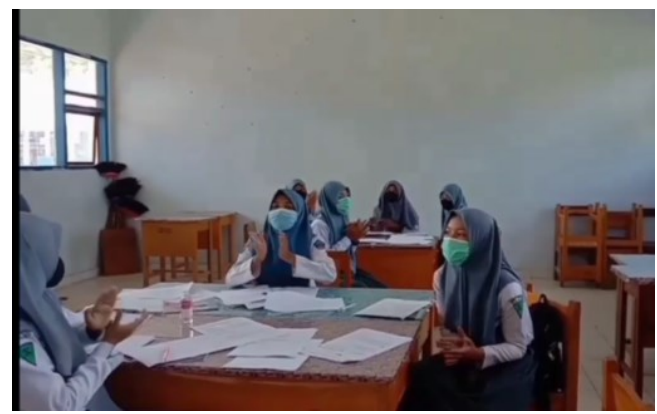

Gambar 6. Siswa memberikan aplaus pada teman yang telah menyampaikan jawaban

Pada akhir pembelajaran, guru memberikan evaluasi kepada pesertra didik. Hasil yang diperoleh adalah sebagai berikut:

\begin{tabular}{|l|l|c|}
\hline No & Hasil Tes Evaluasi I & Siklus I \\
\hline 1 & Rata-rata & 82,92 \\
\hline 2 & Tuntas & $88,89 \%$ \\
\hline 3 & Tidak Tuntas & $11,11 \%$ \\
\hline 4 & $\begin{array}{l}\text { Ketuntasan belajar } \\
\text { secara klasikal }\end{array}$ & Tuntas \\
\hline 5 & Jumlah Siswa & 18 siswa \\
\hline
\end{tabular}

Tabel 3. Hasil Tes Evaluasi Siklus II

Berdasarkan tabel di atas, pada siklus II diperoleh ketuntasan belajar yaitu $88,89 \%$. Dari nilai persentase tersebut sudah mencapai ketuntasan $75 \%$ yang diharapkan karena terdapat 11,11\% siswa yang mendapatkan nilai dibawah $\mathrm{KKM}=$ 70

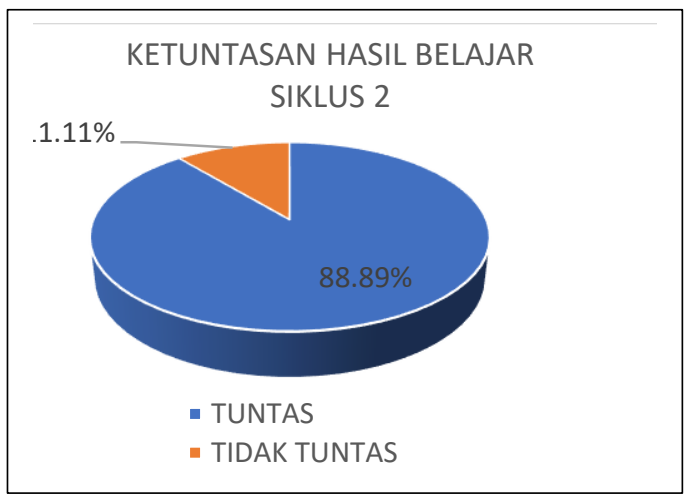

Dari diagram diatas Nampak jelas secara klasikal mengalami ketuntasan $89 \%$ yang melebihi ketuntasan yang direncanakan minimal $75 \%$ 
Pada tahap terakhir ini yaitu refleksi dan analisis, dimana peneliti bersama sebagai kolaborator dan observer menganalisis sekaligus mengevaluasi proses pembelajaran pada siklus II, apakah tindakan yang telah diberikan sudah sesuai atau belum dengan konsep penelitian yang telah direncanakan. Kemudian hasil penelitian siklus II dibandingkan dengan indikator keberhasilan.

Proses pembelajaran pada siklus II ini, tampak siswa mampu belajar mandiri, lebih kondusif, dan turut aktif kegiatan pembelajaran.

Berikut ditampilkan tabel perolehan siklus 1 dan siklus 2

Berdasasarkan analisis data tentang hasil belajar siswa pada siklus I dan siklus II terjadi kenaikan. Untuk lebih jelasnya dapat dilihata pada tabel berikut:

Tabel Nilai Hasil Belajar Siklus I dan Sikluas II

\begin{tabular}{|c|l|c|c|}
\hline \multirow{2}{*}{ NO } & \multirow{2}{*}{ NAMA } & \multicolumn{2}{|c|}{ NILAI HASIL BELAJAR } \\
\cline { 3 - 4 } & SISWA & SIKLUS I & SIKLUS II \\
\hline 1 & A P F & 58 & 85 \\
\hline 2 & A J & 52 & 77,5 \\
\hline 3 & A W & 80 & 92,5 \\
\hline 4 & A & 72 & 65 \\
\hline 5 & C N & 82 & 85 \\
\hline 6 & G & 56 & 90 \\
\hline 7 & G D W & 70 & 85 \\
\hline 8 & H & 56 & 67,5 \\
\hline 9 & L P & 64 & 80 \\
\hline 10 & M & 72 & 77,5 \\
\hline 11 & N Y & 72 & 92,5 \\
\hline 12 & P B & 62 & 85 \\
\hline 13 & R R & 48 & 75 \\
\hline 14 & SE A & 88 & 92,5 \\
\hline 15 & SI A & 76 & 75 \\
\hline 16 & S S & 72 & 92,5 \\
\hline
\end{tabular}

\begin{tabular}{|c|l|c|c|}
\hline 17 & V P & 70 & 85 \\
\hline 18 & W S & 74 & 90 \\
\hline \multicolumn{2}{|c|}{ RATA-RATA } & $\mathbf{6 8 , 0 0}$ & $\mathbf{8 2 , 9 2}$ \\
\hline KETUNTASAN & $\mathbf{6 1 , 1 1 \%}$ & $\mathbf{8 8 , 8 9 \%}$ \\
\hline
\end{tabular}

Dari tabel diatas nilai rata-rata menunjukan kenaikan nilai hasil belajar siswa. Dimana pada siklus I nilai rata-rata hasil belajar siswa 68,00 sedangkan pada hasil belajar pada siklus II naik menjadi 82,92 .

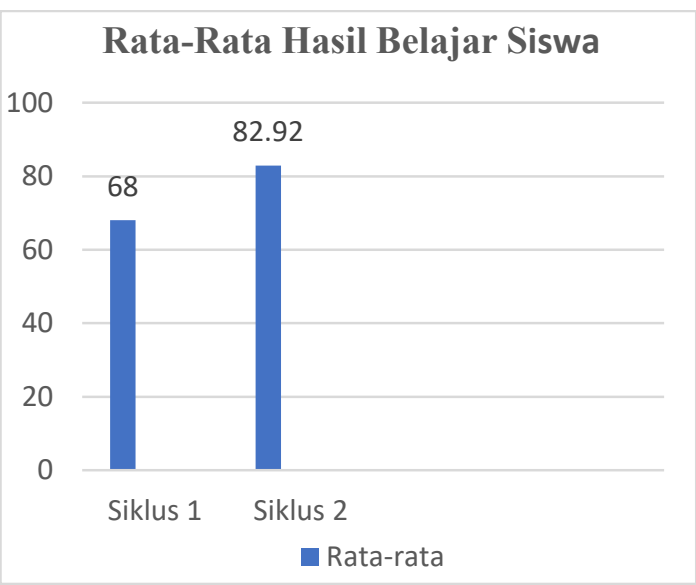

Grafik 4. Nilai Rata-rata Siklus 1 dan 2

Begitu pula pada Ketuntasan siswa pada siklus I persentase ketuntasan mencapai $61,11 \%$ sedangkan pada siklus II naik menjadi 88,89\%. Untuk lebih jelasnya dapat dilihat pada grafik dibawah ini. 


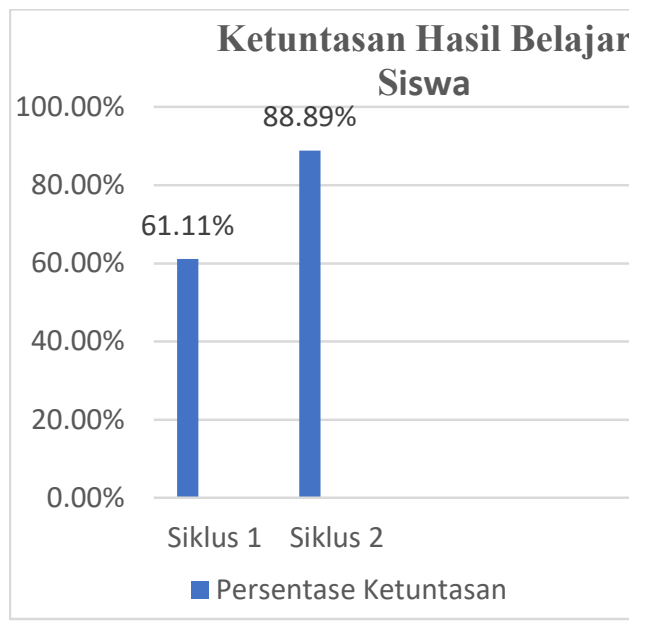

Grafik 5. Ketuntasan belajar siklus 1 dan siklus 2

Hasil penelitian pada grafik diatas menunjukkan bahwa penerapan pembelajaran Matematika dengan menggunakan Lembar Kerja Peserta Didik (LKPD) mampu meningkatkan hasil belajar siswa. Dimana diperoleh nilai ratarata siswa pada siklus 168 dan mengalami kenaikan pada siklus II adalah 82,92 diatas nilai KKM dan ketuntasan klasikal mencapai $88,89 \%$ diatas indikator ketuntasan keberhasilan yang ditetapkan sebesar 75\%. Mengingat indikator keberhasilan telah tercapai, maka penelitian tindakan kelas ini dihentikan di akhir siklus II.

\section{PENUTUP}

\section{Simpulan}

Berdasarkan hasil penelitian tindakan kelas yang dilakukan sebanyak dua siklus diperoleh nilai rata-rata kelas pada siklus 1 yaitu sebesar 68 dan ketuntasan klasikal sebesar 61,11\%.
Sedangkan pada siklus 2 nilai rata-rata kelas naik menjadi 82,92 dan ketuntasan belajar klasikal sebesar 88,89\%. Hasil penelitian ini dapat disimpulkan bahwa penggunaan lembar kerja peserta didik berhasil meningkatkan hasil belajar siswa pada materi matriks.

\section{Saran}

Beberapa saran yang dapat diberikan untuk penggunaan LKPD untuk meningkatkan hasil belajar peserta didik adalah: 1) Bagi Guru, Guru dapat mengunakan LKPD pada materi matriks dalam proses belajar mengajar; 2) Bagi Siswa, Penggunaan LKPD diharapkan dapat menambah minat belajar siswa dan dapat memotivasi siswa dalam belajar; 3) Bagi Sekolah, Penggunaan LKPD pada materi matriks dapat sebagai masukan dalam menyusun program untuk peningkatan kualitas sekolah dan dapat memberikan fasilitas lebih dari sekolah sehingga dapat digunakan oleh siswa dan guru

\section{UCAPAN TERIMA KASIH}

Ucapan terimakasih yang sebesarbesarnya disampaikan kepada Ibu Sri Suryanti, M.Si selaku dosen pembimbing dan Ibu Dra. Masfufah selaku Guru Pamong. Tak lupa juga terima kasih kepada Bapak Mardin, S.Pd selaku Kepala SMK Negeri 1 Tirawuta telah 
memberi tempat dan waktu untuk pelaksanaan penelitian ini. Dan Guru guru teman sejawat yang sudah mendukung pelaksanaan kegiatan penelitian ini. Sehingga berjalan lancar

\section{DAFTAR PUSTAKA}

Arikunto, Suharsimi. 2006. Prosedur penelitian : suatu pendekatan praktik. Jakarta : Rineka Cipta

Firdaus, Anisa. 2013. Pengertian Belajar dan

Mengajar.

http://firdausanisaa.blogspot.com/2

013/09/iii-pengertian-belajarmengajar.html (diakses 13 Oktober 2020)

Hidayat, Syarif. 2013. Pengaruh Kerjasama Orang Tua Dan Guru Terhadap Disiplin Peserta Didik Di Sekolah Menengah Pertama (SMP) Negeri Kecamatan Jagakarsa Jakarta Selatan. https://d1wqtxts1xzle7.cloudfront.n et/54635391/129-373-2-

PB.pdf?1507241066=\&responsecontent-

disposition $=$ inline $\% 3 \mathrm{~B}+$ filename $\%$ 3DPENGARUH KERJASAMA O RANG TUA DAN GURU TE.pd $\underline{f \& \text { Expires }=1602596816 \& \text { Signature }}$ $=\mathrm{ebVdXK10k1RGPWzua4zZtJkBf7}$ hYKBT D2ehv9qjUxASsAjivi6rM JMZiBeFzi8UqirOh21g VHkv2Mp EHiMEVvgsiooVLjiSgJdRsp $\sim$ AW Zpk3ptNpzH1gB7AMvs8flGsh8xiYhRofGeZyna4tB52PkSFTeVZV8 rdiG3b3C $\sim$ rDGWVUN39IQWxo25 jETyK8lgrN7-

qZiWJA11GL0G9fQn28Y5qPeAeb CYlVvD4FNVOTUjyyTHJJ8GUco QJQc65hHXHPq Ed2PHckSNBTu fanyr2dfBlsJSiAI8DD6Tm5AaHK SBVoVk tnHlT1m9Vq9qGB2VBu a 1 24G2f24DtS8vQ \&Key-

Pair-

Id=APKAJLOHF5GGSLRBV4ZA (diakses 13 Oktober 2020)
Jowinta, Vonny. 2017. Pengembangan Lembar Kerja Peserta Didik (LKPD) Menggunakan Model Problem Based Learning Pada Tema 4 Sehat Itu Penting Sebtema 3 Lingkungan Sehat Di Kelas V Sd Negeri 55/I Sridadi. https://repository.unja.ac.id/2343/1/ A1D111133-ARTIKEL.pdf (diakses 13 Oktober 2020)

Kusumah, Wijaya dan Dedi Dwitagama. 2011. Mengenal Penelitian Tindakan. Kelas. Edisi : 2. Jakarta : PT Indeks

Mangelep, Navel. 2012. Penelitian Tindakan Kelas (Suatu Reflektif Terhadap Perbaikan Kualitas Pembelajaran).

https://navelmangelep.wordpress.co m/2012/03/19/penelitian-tindakan-

kelas-suatu-reflektif-dalamperbaikan-kualitas-pembelajaran/ (diakses 13 Oktober 2020)

Sanjaya, Wina. 2016. Penelitian Tindakan Kelas. Jakarta: Kencana Prenada

Suryanti, S., Khikmiyah, F., Zawawi, I., \& Fauziyah, S. (2014). Peningkatan Penguasaan Konsep Matriks Melalui Model Pembelajaran Kooperatif Tipe Two Stay Two Stray (Tsts). DIDAKTIKA: Jurnal Pemikiran Pendidikan, 21(1), 14-27.

Widayati, Ani. 2008. Penelitian Tindakan Kelas. Jurnal Pendidikan Akuntansi Indonesia. Vol. VI. No. 1. https://journal.uny.ac.id/index.php/i pakun/article/view/1793 (diakses 13 Oktober 2020)

Widjajanti. 2008. Pengembangan Lembar Kerja Siswa Bahasa Inggris Bermuatan Nilai Pendidikan Karakter Kelas V Madrasah Ibtidaiyah Semarang. https://journal.unnes.ac.id/sju/index .php/jpe/article/download/3065/283 3/ (diakses 13 Oktober 2020) 